\title{
The Impact of the Telegraph on Anglo-Japanese Diplomacy during the Nineteenth Century
}

\author{
Jack Nicholls \\ The University of Melbourne
}

\begin{abstract}
In our age of high-speed communication, it is easy to underestimate how vast the distance between Britain and Japan really is. At a time when it took over four months for letters to cross from Japan to Britain and back, the first British diplomats posted there were almost completely isolated by their remoteness. The British Ministers to Japan were thus forced to rely on their own judgement in carrying out their allotted task of nurturing British commerce, with occasionally disastrous consequences. This isolation was ended at a stroke in 1870, when Japan was connected to the globe-spanning telegraph network, and the British could send messages via the wire between London and Tokyo in a matter of hours rather than months.
\end{abstract}

This article explores the degree to which the everyday business of a British envoy in Japan was actually changed by the introduction of the telegraph, and asks whether the availability of a technology is enough, in itself, to change society. To answer this question, I look at the careers of the three most distinguished nineteenth-century British diplomats in Japan: Sir Rutherford Alcock (1859-1864), Sir Harry Parkes (18651883) and Sir Ernest Mason Satow (1895-1900).

\section{Keywords}

Britain, diplomacy, telegraph, isolation, technological Determinism

\section{Introduction}

The introduction of the electric telegraph did more to change the practice of international diplomacy than any other innovation in modern history. Prior to the telegraph, diplomats were more than mere mouthpieces for their governments; they were guaranteed a degree of autonomy by way of their isolation. Representatives had to rely on their own judgements and were often forced by events to make significant policy decisions. The more remote from the home government their posts were, the more self-sufficient foreign legations had to be, as well-meaning advice from the homeland could be painfully out of date by the time it reached them. 
In the nineteenth century, few postings were more remote for a British envoy than Japan. Vast gulfs of language, culture and distance separated Imperial Japan from Whitehall, home of Her Majesty's Government. The initial British Ministers in Japan effectively acted with complete independence, as the Foreign Ministry had scant knowledge about the remote Asian country and its instructions took two to three months to arrive in Edo. However, by 1871 the telegraph network had spread to Japan, with wires running unbroken from London to Nagasaki. While the Foreign Office still had a much fuzzier understanding of Japanese politics than the men on the spot, it could now transmit instructions almost instantaneously. ${ }^{1}$ In theory this should have slashed the independence of the British minister. However, as this article will show, although telegrams became an integral part of consular business, the relationship between the Foreign Office and the Minister in Japan remained largely unchanged until the politics of the Anglo-Japanese relationship shifted at the end of the century.

\section{The History of the Telegraph}

The concept of the electric telegraph evolved in the early nineteenth century from previous experiments using masts and flags to transmit information faster than could mounted messengers. ${ }^{2}$ Building on eighteenth-century experiments with electricity, the first telegraphs were designed in the 1840s. They consisted of an electromagnet connected by wires to a marking instrument, such as dials or needles, at the other end. By pressing down to connect the electromagnet to the circuit, a telegrapher would send bursts of current through the line that would then be received and interpreted. Once the significance and potential of the electric telegraph had been grasped around 1845, networks swiftly sprang up across Europe. ${ }^{3}$ The telegraph was neither instantaneous nor infallible; messages would often be garbled or delayed. Nevertheless it revolutionised finance markets, journalism, military operations, espionage and diplomacy: all areas where information was power and quicker access to it gave one an edge.

Twenty years on, the telegraph networks had spread to East Asia. For strategic reasons, Britain required a line to India, while Russia needed to link its Pacific territories with the west. Commercial pressures then drove the wires further east, and competition between Russian- and British-backed firms saw telegraph lines from Siberia reach China and Japan in $1870 .{ }^{4}$ While the Chinese government futilely resisted the technology, in

\footnotetext{
1 And they were men: women were barred from the diplomatic service until 1946. The term 'man on the spot' was coined by John S. Galbraith in an essay analysing how the frontiers of the British Empire were pushed forward in the nineteenth century through the actions of Governors who saw military force as the answer to their problems of a 'turbulent frontier'. See John S. Galbraith, 'The "Turbulent Frontier"', pp. 150-168.

2 Headrick, When Information Came of Age, pp. 194-195.

Ibid., pp. 54-56.

Ahvenainen, The Far Eastern Telegraphs, p. 207.
} 
Japan the new Meiji regime encouraged Western-style development. ${ }^{5}$ Meanwhile, the British Foreign Office had finally accepted the worth of the new technology and by the end of the 1860s the Government had installed private lines directly to the Foreign Office in Whitehall. ${ }^{6}$ The adoption of the telegraph by the British diplomatic service therefore coincided with the connecting of Japan to the world communications network, marking 1870 as the beginning of a new era in British Far Eastern diplomacy.

\section{British Diplomacy}

While diplomacy was an age-old practice, its methods had steadily evolved for centuries prior to the telegraph. Although Britain's seafaring power made the country a successful trading nation by the eighteenth century, its diplomatic relations were then confined to Europe and lacked a formal structure. When the British began to graduate from trade to conquest, their activities in far-flung corners of the world necessitated more rigorous government monitoring. Thus, in 1782 the Foreign Office was formed, under the aegis of the Secretary of State for Foreign Affairs (the Foreign Secretary). He oversaw a network of British diplomats who conducted negotiations with foreign powers and sent back official reports - despatches - on local affairs.

The conduct of diplomatic relations within Europe was standardised at the

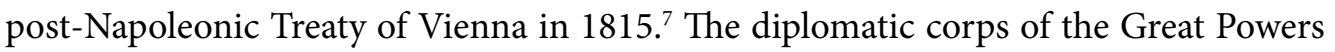
were divided into three ranks: Ambassador Extraordinary and Plenipotentiary, Envoy Extraordinary and Minister Plenipotentiary, and Chargé d'Affaires. Three years later an intermediate 'Resident Minister' position was also recognised. ${ }^{8}$ The rank of diplomatic representative sent overseas depended on the perceived importance of that posting, but most capitals would have an envoy with 'plenipotentiary' powers allowing them to speak, and even sign binding documents, for a Sovereign. ${ }^{9}$ These ministers and ambassadors abroad communicated with Whitehall via despatches: each one written in longhand, numbered and sent home by mail or messenger. ${ }^{10}$

This restructured Diplomatic Corps was dealing with an ever-expanding British presence in Asia. The subjugation of India continued apace, and the First Opium

\footnotetext{
5 There were some Chinese officials who argued against a conservative approach of course, notably the modernising Li Hongzhang, but their views did not prevail. See Erik Baark, Lightning Wires, pp. 73-74.

6 Ibid., p. 148.

7 Article 1 of the Vienna Règlement sur le rang entre les agents diplomatiques reads as follows:

Art. 1. - Les employés diplomatiques sont partagés en trois classes: celle des ambassadeurs, légats ou nonces; celle des envoyés, ministres ou autres, accrédités auprès des souverains; celle des chargés d’affaires, accrédités auprès des ministres chargés du portefeuille des affairs étrangères. Satow, A Guide to Diplomatic Practice, p. 149.

8 Resident Ministers were inferior to Ministers Plenipotentiary and above Chargés d'Affaires, and were formally recognised at the Conference of Aix-laChapelle in 1818. Satow, A Guide to Diplomatic Practice, p. 156.

9 Jones, The British Diplomatic Service, p. 99.

10 Ibid., p. 119.
} 
War (1839-1843) brought Hong Kong under British rule and forced the opening of certain coastal Chinese cities to British citizens. The period marked the high-point of a moralistic, interventionist foreign policy (sometimes called 'gunboat diplomacy') that saw the threat of British military force deployed to advance commercial and strategic interests outside Europe. ${ }^{11}$ As often as not, this aggression was spearheaded by men on the spot, rather than directed from Whitehall, and 'wars might be fought and the issue decided before news of their outbreak reached London.' ${ }^{12}$ To non-European peoples, the British could appear belligerent and condescending, as the Japanese were to observe at firsthand in the nineteenth century.

\section{Literature Review}

Diplomatic history is a well-mined field, but by and large it ignores the impact of communications technology, the subject of this article. There are, however, some relevant texts. Raymond Jones' The British Diplomatic Service analyses the degree to which the telegraph changed diplomacy, and while Jones considers its impact colossal, he argues that issues of expense hindered its effectiveness for Westerners in East Asia; a position which my own research has borne out. ${ }^{13}$ As for the relationship between the Foreign Office and the men on the spot, John Galbraith wrote an outstanding and influential article, although it ignores Japan and contains only cursory mention of the telegraph. ${ }^{14}$ The most relevant study of the telegraph's introduction to Asia came from Jorma Ahvenainen in his 1981 publication The Far Eastern Telegraphs, a thorough history of the competing companies which laid lines into China and Japan. ${ }^{15}$

However, a detailed examination of the telegraph's impact on diplomacy had to wait until 2003, when David Paull Nickles released Under the Wire. ${ }^{16}$ The book chronicles how telegraphy shook up diplomacy, and the methods by which diplomats manipulated the system to their own advantage, concluding that in the end the new technology devastated the autonomy of the man on the spot. In contrast, Daniel Headrick, in his book The Invisible Weapon, holds that telegraphy did not dramatically increase government control on the imperial fringes due to issues of cost, garbling of messages and overly independent officials abroad. ${ }^{17}$

The belief that the telegraph would have automatically diminished the role of

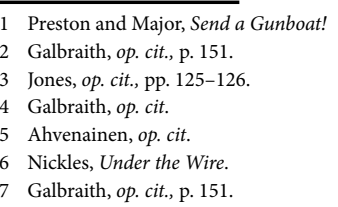


diplomats is a form of 'technological determinism'; a theory that technological change fundamentally shapes events and behaviour. ${ }^{18}$ For my case, I believe that the technology of the telegraph potentially reduced Ministers to puppets of their respective Foreign Services, but this was forestalled by the problems inherent in long-distance telegraphy. While the telegraph certainly had an immediate effect on the position of diplomats on the spot, it was not until their governments had enough incentive to prioritise the AngloJapanese relationship that they saw their policy-making capabilities truly curtailed.

\section{Sir Rutherford Alcock: 1859-1864}

From the seventeenth to the nineteenth century, Japan was a stable and insular state in which lip-service was paid to the Japanese Emperors, but the country was actually governed by the shogun, whose power stemmed from force. The shogun oversaw a military government known as the bakufu, and regional power was held by powerful feudal rulers called daimyo. Since the 1630s, the bakufu had successfully closed Japan to foreign trade and negotiation. It was forbidden, on pain of death, for Japanese citizens to go abroad, Christianity was outlawed and foreign vessels were restricted to Nagasaki. ${ }^{19}$ The Dutch were the only Westerners permitted to conduct trade with the Japanese, and only then on Deshima, an island in the Nagasaki bay. ${ }^{20}$

Yet the world was changing. By the first decades of the nineteenth century, Qing China was being increasingly penetrated by Western economic interests, and this came to a head in the First Opium War (1839-1842) when Britain humiliated the Chinese. From then, it did not take long for the blow to fall on Japan. In 1853, Commodore Matthew Perry of the US Navy arrived in the Uraga Channel with four state-of-theart steam-ships. ${ }^{21}$ Faced with this threat, the bakufu was blackmailed into signing the Treaty of Kanagawa in 1854, opening two ports to foreign trade. ${ }^{22}$ The British quickly followed America's lead, and the same year Japan signed a 'Convention for Regulating the Admission of British Ships into the Ports of Japan', followed in 1858 by a more detailed 'Treaty of Peace, Friendship, and Commerce between Her Majesty and the Tycoon of Japan.' ${ }^{23}$ This treaty emphasised 'commercial intercourse' between the two island states, although not on an equal footing. British citizens were to be immune from prosecution by Japanese authorities and given immediate commercial access to several

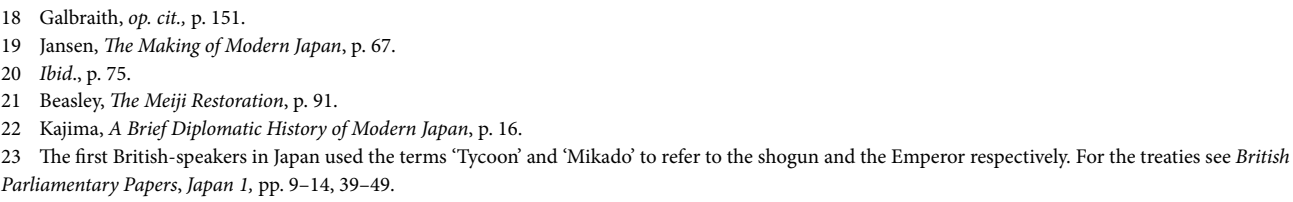


port towns, which came to be known as 'treaty ports. ${ }^{24}$ Foreigners were also allowed a limited presence in Edo and Osaka. Finally, the treaty allowed a British envoy to take up residence in the country, marking the beginning of modern Anglo-Japanese diplomacy in 1858. The treaty was, of course, negotiated by a diplomat with plenipotentiary powers, Lord Elgin. ${ }^{25}$

Sir Rutherford Alcock (1809-1897) was the man chosen as Britain's pioneering representative in Japan. A medical doctor who had joined the diplomatic service, Alcock had served fifteen years as Consul in China. ${ }^{26}$ In comparison to the cosmopolitan ports of China, Japan was a lonely position for a British gentleman: Alcock had only five staff with him in Edo, and he held a low opinion of the British merchants who plied their trade locally. These hardships were partially ameliorated by Alcock's annual salary: a generous $£ 2000$ in $1860 .^{27}$ Meanwhile, a gulf of language separated Alcock from his Japanese hosts. Until interpreters like the young Ernest Satow could be trained, exchanges between the British and Japanese had to be first rendered into Dutch before translation into the other language. Isolated by the language barrier and his distance from Britain, Alcock had to be guided by the general instructions he had received before his arrival: to uphold Britain's newly won Treaty rights and encourage the expansion of British commerce in Japan. ${ }^{28}$

As was his duty, Alcock immediately began sending despatches back to John Russell (1792-1878), the Foreign Secretary. Russell replied when able, but correspondence between him and Alcock was decidedly one-sided. Russell was responsible for British ministers across the world, most in more immediately important outposts than Japan, where British trade was still in its infancy. Even if he had had the time, Russell was hampered by his ignorance of Japanese customs and politics. Unsurprisingly then, Alcock received little meaningful input from home in his first years at Edo. ${ }^{29}$

Given his isolation, Alcock was forced to improvise and sometimes conduct policy on the fly. This was illustrated within two months of his landing in Japan. Alcock had arrived in the country with the title of Resident Minister, lacking full authority to make policy in the name of Queen Victoria. Realising the importance with which the Japanese regarded protocol, and discovering that his American counterpart

\footnotetext{
24 The treaty opened the ports of Hakodadi [sic], Kanagawa and Nagasaki on 1 July 1859, and declared that 'Nee-e-gata' and 'Hiogo' (Kōbe) would be opened 1 January 1863. Checkland, Britain's Encounter with Meiji Japan, p. 5.

25 Fox, Britain and Japan, pp. 42-43.

26 Cortazzi, British Envoys in Japan, p. 9.

27 Alcock to Russell, Despatch 41, Inclosure A, 'Statements of the Expenses of Her Majesty's Diplomatic and Consular Establishment in Japan', 13 July 1860,

in Bourne and Watt, British Documents on Foreign Affairs, pp. 8-11.

28 Cortazzi, op. cit., p. 14.

29 Cortazzi has described Russell's despatches in this period as 'inconsistent and weak', Cortazzi, op. cit., p. 37.
} 
was a Minister Plenipotentiary, Alcock awarded himself a promotion to Minister Plenipotentiary and Consul-General without waiting for confirmation from Whitehall. He penned an explanation home, explaining his belief that time had been of the essence:

[I] Felt too strongly, on the spot, the critical nature of our first relations with Japan, and the great importance of taking a position which may enable the British Agent to make head against the hostile elements in full action and keep them in check. ${ }^{30}$

The promotion allowed Alcock to negotiate directly with the bakufu's Ministers for Foreign Affairs, and Alcock stated his willingness to resign if Her Majesty's Government felt that he had overstepped himself, although he urged them to retain the new rank for his successor. In the circumstances, Alcock no doubt made the right decision. Nonetheless, it was an extraordinary illustration of the power an envoy on the periphery of the British Empire could have, for lack of any alternatives. The Foreign Office could hardly countermand the decision, four months after the Japanese had begun dealing with the new arrangement. Regardless, there is no evidence that Russell was perturbed by these events. He wrote back assuring Alcock that, 'The Queen has been graciously pleased to confer upon you the rank of Her Majesty's Envoy Extraordinary and Minister Plenipotentiary in Japan. ${ }^{31}$

The complexities of the Japanese situation meant that Alcock was not always able to follow his instructions to the letter. The origin of such divergences, when they arose, lay in the difficulties Alcock had in carrying out his government's policy in a country run by a passive-aggressive bakufu. As Russell wrote to Alcock, Her Majesty's Government wanted 'to maintain and, if possible, enlarge [trade with Japan], and you are to preserve undiminished the reputation of the British name' but it had 'no desire to quarrel with Japan. ${ }^{32}$ The value of Japanese trade was not worth the vast expense of fighting a war with the country. This left Alcock with a dilemma. He needed the potential threat of force to wring concessions from the bakufu, but he did not want to begin a conflict at a time when Britain was already battling China in a second Opium War (1856-1860). It was a delicate line, and in the eyes of the Foreign Secretary he came dangerously close to crossing it in late 1859. Faced with bureaucratic obfuscation, Japanese evasion of Treaty responsibilities and assassination attempts on the legation, an infuriated Alcock wrote to the Japanese Ministers for Foreign Affairs insisting on a meeting, warning that:

30 Alcock to Russell, 10 August 1859, no. 12 of 'Correspondence with Her Majesty's Envoy Extraordinary and Minister Plenipotentiary in Japan', 1860(2648) LXIX, p. 28, in British Parliamentary Papers, Japan 1, p. 84.

31 Russell to Alcock, 8 December 1859, no. 25 of 'Correspondence with Her Majesty's Envoy Extraordinary and Minister Plenipotentiary in Japan', 1860(2648)LXIX, pp. 58-59, in British Parliamentary Papers, Japan 1, pp. 114-115.

32 Russell to Alcock, 23 November 1861, no.13 of 'Correspondence Respecting Affairs in Japan, July to November 1861', 1862(2929)LXIV, pp. 72-73, in British Parliamentary Papers, Japan 1, pp. 366-367; Russell to Alcock, 8 April 1861, no. 5 of 'Correspondence Respecting Affairs in Japan, March and April, 1861', 1861(2829)LXVI, pp. 11-12, in British Parliamentary Papers, Japan 1, pp. 213-214. 
What I have to communicate is of such grave importance that on the result of our interview may depend the continuance of amicable relations between the two countries $\ldots$ on its result may ultimately depend a state of peace and war between the two countries. $^{33}$

Lord Russell received a copy of Alcock's letter a few months later, and was clearly worried by it. He wrote back explaining the position of Her Majesty's Government, and the problems engendered by Alcock's attitude:

Her Majesty's Government approve your general conduct; but it were to be wished that you had not threatened war. If the grievances are not redressed and war is not made, the character of the British Government is in some degree impaired; if war is made to enforce the observance of a Commercial Treaty, we run the risk of engaging in protracted hostilities, and of earning a reputation for quarrelling with every nation in the East.

... Our intercourse is but newly begun: it should not be inaugurated by war. ${ }^{34}$

By the standards of diplomatic language, this was a sharp rebuke. The episode was an example of the Minister having to take actions which would have been unforeseen when he was appointed, actions that could cause concern in the conservative bureaucracy of Whitehall. The most dramatic example of this was still to come, near the end of Alcock's final term as Minister to Japan. Indeed, Alcock's actions were responsible for ending his position in that country.

On 25 June 1863 an American trading vessel was fired upon by Japanese warships in the Shimonoseki Straits that divide Kyūshū from Honshū. ${ }^{35}$ The Straits were controlled by the powerful Chōshū clan, aligned with the anti-foreign clique within the bakufu, and for a year afterwards they were effectively closed to commerce. Alcock believed that if he was going to fulfil his duty of maintaining British trade, he would have to take action. So, on 1 September 1864, with the blessing of the bakufu, a multinational force of warships and marines organised by Alcock appeared in the Straits to destroy the Chōshū gun batteries. ${ }^{36}$ The Chōshū defences were shattered in exchange for light Western losses, and the Japanese surrendered on 8 September. ${ }^{37}$

33 Alcock to the Japanese Ministers for Foreign Affairs, 6 December 1859, inclosure 2 in no. 12 of 'Correspondence with Her Majesty's Envoy Extraordinary and Minister Plenipotentiary in Japan', 1860(2648)91, in British Parliamentary Papers, Japan 1, p. 147.

34 Russell to Alcock, 28 February 1860, no. 44 of 'Correspondence of Sir Rutherford Alcock, Minister Plenipotentiary to Japan', 1860(2648)LXIX, p. 98, in

British Parliamentary Papers, Japan 1, p. 154.

35 Fox, op. cit., p. 113.

36 Satow, A Diplomat in Japan, pp. 102-115.

37 Ibid., pp. 114-116. 
Despite the strategic success of this mission, it sparked a furore in London. Upon receiving word of Alcock's intentions in August, Lord Russell wrote a response recalling the Minister to London 'to explain the actual situation of affairs, and confer with Her Majesty's Government as to the measures to be taken. ${ }^{38}$ A few days later he again cautioned against military action. ${ }^{39}$

Quite unaware of Russell's dismay, Alcock launched the Shimonoseki assault and wrote back a cheery summary of the events, stating 'I would fain hope the course I have taken will have been approved even before the result could be known' and that 'the policy I am now directed to follow, as summed up in four heads by your Lordship, it has been my fortune to anticipate in a great degree, if not in every particular. ${ }^{40}$ Russell received the lengthy despatch on 27 November and understanding the affair more clearly responded in a much friendlier tone that 'Your despatch of the $28^{\text {th }}$ of September is a successful vindication of the policy you have pursued' and that given the circumstances Alcock had made the correct decision. ${ }^{41}$

At that stage, Alcock had only received Russell's first despatch and it was now his turn to be unhappy, as were his staff. ${ }^{42}$ As ordered, he arranged to voyage back to England, but before departing produced one final despatch eloquently defending his policy against what he saw as Russell's 'censure and condemnation'. ${ }^{43}$ He pointed out the impossibility of fulfilling his dual instructions of defending British interests and taking no potentially inflammatory action, especially against 'Asiatics' who 'respect[ed] only force. ${ }^{44}$ In his letter, Alcock summed up beautifully the tyranny of distance that shaped his predicament:

It could be no reproach to the members of the Cabinet at 14,000 miles distance, to be deceived as to the course most likely to conduce to the desired end; but it would have been a great disgrace to Her Majesty's Representative on the spot, if he had failed to discern the true bearing of events as they passed under his eye ... In doing this, I undoubtedly employed the means placed at my disposal for that end, in a way that my recent instructions seem to condemn. But this I attribute entirely to the difficulty of

38 Russell to Alcock, 8 August 1864, no. 45 of 'Correspondence Respecting Affairs in Japan', 1864(3303)LXVI, p. 54, in British Parliamentary Papers, Japan 2, p. 212.

39 Russell to Alcock, 25 August 1864, no. 50 of 'Correspondence Respecting Affairs in Japan', 1864(3303)LXVI, p. 57, in British Parliamentary Papers, Japan 2, p. 215.

40 Alcock to Russell, 28 September 1864, no. 67 of 'Correspondence Respecting Affairs in Japan', 1864(3303)LXVI, pp. 119-122, in British Parliamentary Papers, Japan 2, pp. 277-280.

41 Russell to Alcock, 2 December 1864, no. 71 of 'Correspondence Respecting Affairs in Japan', 1864(3303)LXVI, pp. 127-128, in British Parliamentary Papers, Japan 2, pp. 285-286.

42 In his memoirs, Satow wrote that Russell's despatch amounted to 'A censure upon his [Alcock's] conduct', both unfair and irrelevant, Satow, A Diplomat in Japan, p. 134.

43 Alcock to Russell, 19 November 1864, no. 88 of 'Correspondence Respecting Affairs in Japan', 1864(3303)LXVI, pp. 148-155, in British Parliamentary Papers, Japan 2, pp. 307-313.

44 Ibid., p. 312. 
measuring with accuracy, at such a distance, the real bearing of the action taken, and the progress of events which led to it ...

... I would rather, and I am satisfied so would your Lordship in a similar situation, incur temporary censure for a seeming departure from instructions dictated in ignorance of the actual circumstances, and at an interval of several months, by which the real object of Her Majesty's Government should be secured, than claim merit for a blind obedience, the result of which must be failure and disaster. ${ }^{45}$

Having missed Russell's apologetic despatch of 2 December, Alcock then endured an undoubtedly stressful voyage of many weeks, only to arrive back in London to be feted for his 'meritorious services' in Japan. Indeed, Russell rather unconvincingly denied that there had ever been any implication that Alcock was being censured or fired. ${ }^{46}$ Despite this, Alcock was never to return to Japan, instead being promoted to the position of Minister at Beijing. ${ }^{47}$

Thus, Alcock's tenure in Japan drew to a close in 1864, shortly before great upheavals were set to take place there. In hindsight, the correspondence between Alcock and Russell resembles a comedy of errors, but it is an indication of the serious problems Britain faced in administering her interests across the globe. While Russell and Alcock shared the same goals when it came to Japan, their situations gave them different outlooks as to the best means to achieve them. For Russell and the Foreign Office, Japan was but one minor interest in a globe-spanning Empire, easily overshadowed during a period of crisis in China. ${ }^{48}$ On the other hand, Alcock's career and reputation rested on his success with the Japanese. Given this, and the pressures of his circumstances, Alcock was perhaps prepared to go further than the Foreign Office had envisioned would be necessary. Had he access to a telegraph, Alcock's career might have proceeded quite differently - which brings us to his successor.

\section{Sir Harry Parkes: 1865-1883}

Sir Harry Parkes (1828-1885) arrived in Japan in April 1865, only thirty-eight years of age, and was to hold the position of Minister Plenipotentiary for an impressive eighteen years, until he was transferred to Beijing in 1883 . He had therefore already

$45 \quad$ Ibid., p. 311.

46 Russell to Alcock, 31 January 1865, no. 89 of 'Correspondence Respecting Affairs in Japan', 1864(3303)LXVI, pp. 155-156, in British Parliamentary Papers, Japan 2, pp. 313-314; again, Satow disagreed, pointing out in his account of the affair that 'an invitation to return home is equivalent to the removal of a diplomatic officer from his employment', in Satow, A Diplomat in Japan, p. 134.

47 Satow, A Diplomat in Japan, p. 141.

48 Japan was not even officially recognised in the Foreign Office organisation until 1865, and even then it was hidden away with China and Siam in the 'American Department', Steeds and Nish, China, Japan and Nineteenth Century Britain, pp. 12-13. 
been stationed in Japan for five years by the time that a direct telegraphic connection with Europe was installed. Parkes' career thus straddles the threshold between isolation and connectedness in international diplomacy. By studying Parkes, we can see the degree to which the business of a man on the spot was immediately changed by this new technology.

Parkes was eminently well-suited to the post of Minister in Japan by his experience, if not necessarily by his personality, having served previously as consul in China, including a period under Sir Rutherford Alcock in the 1840s. His work in China was eventful, as he played a leading role in the lorcha Arrow incident that provoked the Second Opium War, and was held captive by the Chinese in the final weeks of that conflict. ${ }^{49}$ His zealotry may have grated on Japanese sensibilities, but nobody could deny that Parkes was a man of action, not given to the doubts that had plagued Alcock.

When Parkes arrived in Japan, he was guided by a set of instructions from Lord Russell in the same mould as those sent to Alcock: to 'pursue a firm but conciliatory policy toward the Tycoon and his Ministers. ${ }^{50}$ Working from these guidelines Parkes continued business much as usual in Japan, but events were to overtake him. In November 1867, the shogun formally surrendered his powers to the Emperor, to the dismay of his vassal daimyo. By January 1868, simmering hostility between these supporters of the shogunate and those of the Emperor exploded into civil war. Parkes kept a low profile, and by mid-1869, the fighting was over and the progressive forces of the Emperor had triumphed..$^{51}$ Political change had come to Japan, and with it, technological change too. That year, the first telegraph line in Japan was raised between Tokyo, the recently renamed capital, and Yokohama; encouraged by the new Government which saw technology as the key to strengthening the country to match Europe. ${ }^{52}$ Japan was entering a new era of modernisation, and Parkes was an eager advocate of such a course. He wrote to the new Foreign Secretary, the Earl of Clarendon:

I have had frequent opportunities of discussing with the Mikado's Government the desirability of introducing Railways and Telegraphs into Japan. It is essential ... that improved means of communication should be provided. ${ }^{53}$

49 Hurd, The Arrow War.

50 Russell to Parkes, 8 April 1865, no. 8 of 'Correspondence Respecting Affairs in Japan, 1865-1866', 1866(3615)LXXVI, pp. 8-9, in British Parliamentary Papers, Japan 2, pp. 380-381.

51 Hane, Modern Japan, p. 81

52 See FO 46/125, Unknown (Japanese) author, no 72, insert no. 1, 'An Essay on the Introduction of Railways and Telegraphs', March 1870, enclosed in Parkes to Clarendon, no. 65, 21 April 1870.

53 FO 46/125, Parkes to Clarendon, no. 65, 21 April 1870. 
Back in England on leave in 1872, Parkes repeated his sentiments in a statement before a committee of the House of Commons, where he reported that 'a very considerable portion of my time and my duties' was taken up by encouraging the Japanese government in constructing railways and telegraphs. ${ }^{54}$ The questions the committee went on to ask Parkes about the Far East were of a very basic nature, and showed how ignorant most of the British government remained about the region. ${ }^{55}$ Even with a telegraphic connection in place, few in Britain had the interest or capacity to cable Parkes relevant instructions about his post.

Parkes' labours bore fruit in 1871 when a submarine cable was laid between Nagasaki and Shanghai by the Great Northern Telegraph Company. ${ }^{56}$ This allowed Parkes, in theory, to refer queries home and get a response within hours. There is little indication, however, that Parkes' role was substantially changed by this dramatic modernisation. The evidence of the Foreign Office files suggests that telegraphing was an expensive, bureaucratic nightmare. Each telegram received by the Foreign Office spawned a series of internal memos regarding compensation for the sender; and the

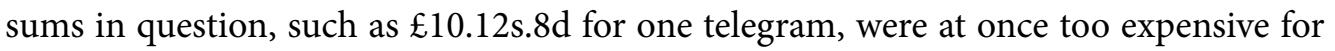
everyday business, and too minor to be worth the trouble they caused ${ }^{57}$ It is unsurprising that the Treasury discouraged frivolous telegraphing and reminded diplomats that telegrams required economy. ${ }^{58}$

Concision was a virtue, but telegrams could become so compressed as to make understanding difficult..$^{59}$ To protect against espionage, telegrams were usually encoded as well, and the resulting nonsense words were more liable to mistakes in transfer by telegraph operators, or erroneous decipherment. ${ }^{60}$

Given these myriad potential problems, it is unsurprising that a diplomat of the old Palmerstonian mould did not embrace the telegraph. The vast majority of Parkes' business was still conducted through handwritten despatches. Yet while the telegraph may not have revolutionised Parkes' day-to-day work, it did prove decisive in curtailing an inflammatory plan of his to annex an island off the south coast of Korea.

\footnotetext{
54 Daniels, Sir Harry Parkes, p. 127.

55 Ibid., pp. 125-130.

56 Great Northern, a Danish firm backed by Russian capital, was one of the two major telegraph companies then operating in the Far East. Eiichi Itoh, 'The Danish Monopoly on Telegraph in Japan', p. 89.

57 FO 46/101, Rogers to the Under-Secretary of State, 6 March 1868; FO 46/102, Rogers to Hammond, 2 May 1868; FO 46/103, Treasury Chambers to the Under-Secretary of State, 2 November 1868; FO 46/103, Draft, 21 November 1868; FO 46/103, Treasury Chambers to the Under-Secretary of State, 2 December 2 1868; FO 46/101, Rogers to the Under-Secretary of State, 6 March 1868.

58 British Parliamentary Papers, 1859 (Session 1) 14, 115; Circular, 25 September 1858, in Jones, op. cit., p. 123; Steeds and Nish, China, Japan and Nineteenth-Century Britain, p. 13.

59 Nickles, Under the Wire, p. 175.

60 For example, see FO 46/192, Parkes to Derby, telegram, 20 July 1875. The Foreign Office files contain three versions of the important telegraph, deciphered by different branches of government. While they are more or less the same, each version contains mistranslations and missing words, indicating the difficulties with telegram decipherment in this period.
} 
Parkes' scheme was devised in July 1875 at a time when the Meiji government was starting to eye a bigger role for Japan in regional politics, notably in Korea, which remained closed to foreign trade just as Japan had been a quarter of a century earlier. Meanwhile, the steady expansion of the Russian empire had taken it to the Korean border, and there were rumours of conflict in the near future. ${ }^{61}$ In what Gordon Daniels described as an 'overreaction', Parkes began to fear an impending partitioning of Korea between Russia and Japan, if not other Powers; a similar situation to that occurring in China. ${ }^{62}$ Concerned that this would strengthen Britain's rivals and destabilise the East, Parkes dashed off an enciphered telegram to the Foreign Office, warning:

[d]ifficulties are rising between Japan and Korea, and rupture of relations appears probable. An understanding between Russia and Japan as to attack on Corea is reported. Japanese vessels of war are already engaged in surveying East Coast of Corea. A large German corvette is also sweeping the West Coast with a view, as it is believed, to occupation. ${ }^{63}$

In light of the 'highly probable eventualities' (a conflict), Parkes urged that British naval forces stationed around Japan immediately occupy Port Hamilton (Geomun-Do to its inhabitants): a natural harbour in the Korea Strait, and thus Korean territory. ${ }^{64}$ Parkes also claimed to have the support of the local British admiral for this plan. ${ }^{65}$

Parkes' proposal, tantamount to declaring war on the commercially unimportant state of Korea, was not received warmly back in London. The notes scrawled by Lord Derby (Foreign Secretary 1866-1868) regarding the decrypted telegram show that he was not persuaded by Parkes' counsel, but the Foreign Office dutifully telegraphed Berlin and St Petersburg to see if the British ministers there had heard anything to support Parkes' allegations. ${ }^{66}$ The replies stated that there were no rumours of such an action, nor any hint of deteriorating relations with the Koreans. ${ }^{67}$

Unsurprisingly, Parkes was ordered to abandon his plan, and indeed no portioning of Korea eventuated. Did the telegraph thus avert an unnecessary conflict that could have sparked a scramble for Korea? The tone of Parkes' telegram of 20 July, which warned that Port Hamilton might have been already annexed by another Power

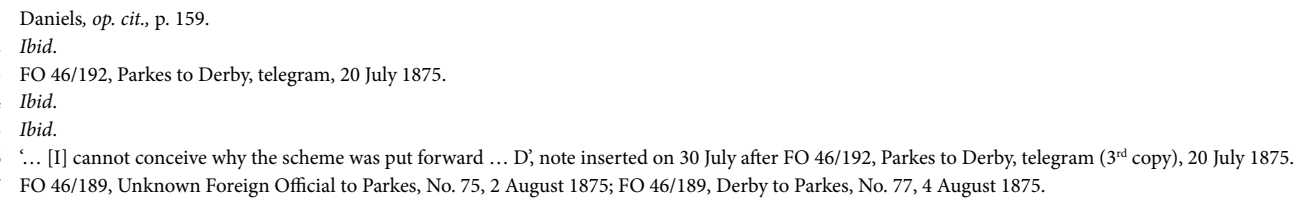


and advocated action within the week, made it clear that the Minister considered the operation to be immediately necessary. ${ }^{68}$ This raises the question of whether, had he lacked access to the telegraph, Parkes would have stuck to the letter of his instructions and not used force to further British policy; or whether he would have followed his own instincts, as Alcock had at Shimonoseki.

Given what we know of Parkes' character, it seems very likely that he would have taken matters into his own hands. It has been convincingly argued by J. Y. Wong that Parkes, then an acting Consul at Canton (Guangzhou), was the driving force behind Britain's aggressive escalation of the Arrow incident which caused the Second Opium War and made his reputation. ${ }^{69}$ Parkes urged his superiors to take a hard line, then he helped plan and took part in the resulting military actions - before London was even aware of what had occurred. ${ }^{70}$ The resulting furore in Britain sparked a snap election and bitter debate, evidence of the controversy that a distant diplomat's actions could cause. ${ }^{71}$

While Parkes may have been less hot-headed in his middle age, there was clearly a risk of a repeat of his warmongering behaviour. In 1864, the delay in communications had led Sir Rutherford Alcock to uphold British interests through force, to the initial horror of his superiors. In 1876, the only thing stopping Sir Harry Parkes from doing the same was the telegraph, which allowed the Foreign Office warning enough to countermand Parkes' plan.

Gordon Daniels believed that the telegraph, which was increasingly becoming the centrepiece of modern diplomacy, dashed Parkes' independence and left him yesterday's man. ${ }^{72}$ This is an exaggeration. As a conservative diplomat, Parkes quite likely did somewhat resent the cables linking him with home. But with the exception of his vetoed Korean venture, Parkes' loss of independence was more symbolic than real. In Parkes' time, Japan was still peripheral to British foreign policy, and telegrams sent at that distance were expensive and unreliable. The telegraph may have hindered Parkes' making a grand military gesture, but it did little to check him otherwise. He remained in his position until 1879, when he left Japan in declining health. He would die in Beijing six years later.

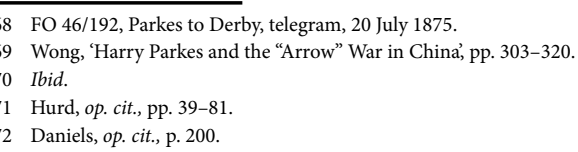




\section{Sir Ernest Satow: 1895-1900}

Sir Ernest Mason Satow (1843-1929), Britain's man in Tokyo from 1895 to 1900, was the most qualified British Minister to be stationed in Japan in the nineteenth century. Satow had served as an interpreter in the Japan legation under both Alcock and Parkes, and his tacit support for the Chōshū and Satsuma men during that period had paid dividends, as many of the friends he had made during the tumultuous Meiji Restoration were now the political elite of Japan. He spoke fluent Japanese, had a Japanese family and came to his post with a deeper understanding of the country than any predecessor. Upon Satow's arrival, Count Ōkuma Shigenobu, one of the most influential of Meiji statesmen, welcomed him as a 'man of weight', contrasting Satow with the efficient but undistinguished men who had held the post of Minister since Sir Harry Parkes. ${ }^{73}$

Satow returned to a country more confident than it had been in the Parkes era. The recent Japanese victory in the Sino-Japanese War (1894-1895) had validated the Meiji reforms of the previous quarter-century. During this conflict, the Japanese had displayed their understanding of the value of communications technology by laying their own telegraph lines across southern Korea. ${ }^{74}$ Meanwhile, British military dominance was slipping and Russian expansionism threatened British and Japanese interests equally. It would seem that the timing was fortuitous for active diplomacy: an increasing number of Japanese policymakers thought that it would make sense for Britain and Japan to conclude a military alliance and Satow was now easily contactable by his government via the telegraph. ${ }^{75}$ However, Whitehall largely left the Minister to his own devices and the Anglo-Japanese relationship stagnated from 1895 to 1900.

This is not to imply that the telegraph was being ignored by the Foreign Office. Even among the most conservative members of the Foreign Service, the telegraph had become an indispensable tool by the 1890s. In 1889 Lord Salisbury (1830-1903), a giant of British conservatism and then holding both the office of Prime Minister and Foreign Secretary, had declared of the Foreign Office that 'we positively exist by virtue of the telegraph. ${ }^{76} \mathrm{After}$ a period in opposition, Salisbury returned to power in 1895 and took up his twin positions once more, dominating British foreign policy until the close of the century.

73 Satow, The Diaries and Letters, p. 214. Satow's immediate predecessors as Minister Plenipotentiary to Japan were Sir Francis Plunkett (1884-1887), Hugh Fraser (1889-1894) and Power Henry le Poer Trench (1894-1895).

74 Daqing Yang, 'Colonial Korea in Japan's Imperial Telecommunications Network', p. 164.

75 Satow noted several conversations with Anglophile Japanese on this subject: PRO 30/33 14/9, Satow to Salisbury, 28 May 1896; PRO 30/33 14/9, Satow to Salisbury, 2 December 1896; PRO 30/33 14/9, Satow to Salisbury, 31 December 1896; PRO 30/33 14/10, Satow to Salisbury, 24 February 1898; PRO 30/33 14/10, Satow to Salisbury, 19 May 1898; PRO 30/33 14/11, Satow to Salisbury, 5 October 1899; all in Satow, The Semi-Official Letters, pp. 37, 61, 64, 98, 118, 176. 76 Salisbury, 'Speech to the Institution of Electrical Engineers', p. 13. 
Parkes had seen the beginnings of the telecommunications revolution in diplomacy; by 1895 Satow was in the middle of it. Satow was himself quick to draw the comparison in a speech he made to the foreign community at Yokohama on the day of his arrival, saying that he hoped to follow Parkes' example 'though the field of diplomatist has greatly diminished since Sir Harry's days."77 This was recognition of how much the telegraph had changed diplomacy. It was a familiar lament, one that could be heard by old-fashioned diplomats throughout the world in this period. But while the telegraph era may have spelled the end of the great diplomatic policymakers, it did not necessarily neuter consular and diplomatic staff completely.

Nonetheless, the telegraph was now the cornerstone of Satow's communications. In his Guide to Diplomatic Practice, Satow wrote that it was a diplomat's duty to utilise the telegraph:

In former times a wide discretion in the interpretation of his instructions was permitted to an envoy, in case it became necessary to take a sudden decision, but in these days, when telegraphic communication is universal, if he is of opinion that his instructions are not perfectly adapted to secure the object in view, he can easily ask for the modification he judges to be desirable. In doing this he will be well-advised to explain his reasons at full length. It is better to spend money on telegrams than to risk the failure of a negotiation. ${ }^{78}$

Of course, Satow's book, written twenty years after his service in Japan, did not necessarily reflect his methods in the 1890s. Still, Satow's official and semi-official correspondence from that period does bear out a picture of a man who made the telegraph part of his working life. The internal communications of the legation were full of telegrams, or references to them; and Satow commissioned a cottage retreat at Lake Chuzenji and induced the [Japanese] Gov. to put up a teleg. line, so that we are in touch with the outer world? ${ }^{79}$

The majority of these diplomatic telegrams were short messages being sent between the consulates within Japan. Sending an international telegram to London remained expensive, prohibitively so for some. ${ }^{80}$ However, as tends to occur when new technologies become mainstream, the price had dropped since the 1870s; by 1897 it cost 7.70 (comparatively inflated) francs per word, compared with 11 francs in $1875 .{ }^{81}$

\footnotetext{
Satow, quoted in The Japan Weekly Mail, 3 August 1985, from Satow, The Diaries and Letters, p. 201.

78 Satow, A Guide to Diplomatic Practice, p. 155

79 PRO 30/33 14/9, Satow to Salisbury, 9 July 1896, in Satow, The Semi-Official Letters, pp. 41-42.

80 One message in the Satow files begins 'Dear Mr. Lowther, the expense of telegraphing practically prevents me from communicating with the Foreign

Office': PRO 30/33 5/5, G.E.H. Barrett-Hamilton to Lowther, 24 September 1897, in Satow, The Correspondence, p. 190.

81 The price continued to drop until it reached 4.88 francs per word by 1913. Ahvenainen, op. cit., p. 205.
} 
Given this, it would seem logical that Satow would have a more harmonious and tightly controlled relationship with the Foreign Office than had his predecessors. Yet while it is true that Satow's daily affairs were dominated by the telegraph in a way unimaginable a few decades before, this had less effect on his position than might have been expected. Although the Foreign Office was capable of contacting him at any time, Satow in fact received little more guidance from Whitehall than had Alcock before him.

Soon after his arrival Satow wrote to Salisbury, 'Perhaps Y.L. [Your Lordship] may think it worthwhile to give me some directions as to the line I shld. take. ${ }^{82}$ Salisbury adhered to a policy that has often, if simplistically, been termed 'Splendid Isolation': Britain aloof from the alliances among the Great Powers, advancing her own interests peacefully while relying on her navy to protect her from aggression. ${ }^{83}$ As such, in response to his Minister's request for instructions, Salisbury encouraged Satow to 'give great attention to the commercial part of your duties', and dismissed Japan's worth as an ally, suggesting that 'in the end they will be convinced that it is in their interest to join with Russia and perhaps with France in cutting up China. ${ }^{84}$ Salisbury had thrown cold water on the idea of an Anglo-Japanese alliance for the moment, and Satow did not often raise the subject in his official despatches. Yet in his semi-official letters, of which he sent seventy-eight to Salisbury during his tenure as Minister, Satow was more garrulous and hinted at his own opinion. ${ }^{85}$ Alongside reporting conversations with Anglophilic Japanese, Satow warned:

If H.M.G were willing, Japan wld. throw herself into our arms. Most of the press advocates a close understanding c. Engld. If we do not take their side, they will be driven to make terms c. Russia. ${ }^{86}$

Salisbury remained silent on the issue, and Satow did not write as strongly on the topic again. Despite this, Satow's despatches home continued to concentrate on political issues and were disparaging about further commercial opportunity for Britain. ${ }^{87}$ This could be seen as contravening Salisbury's instructions, but Satow received little censure for this. Indeed, apart from occasional telegrams, and a message promoting him to the Chinese legation in 1900, Satow received few instructions of any kind from the Prime Minister. ${ }^{88}$ Salisbury's Private Secretary even wrote a sympathetic

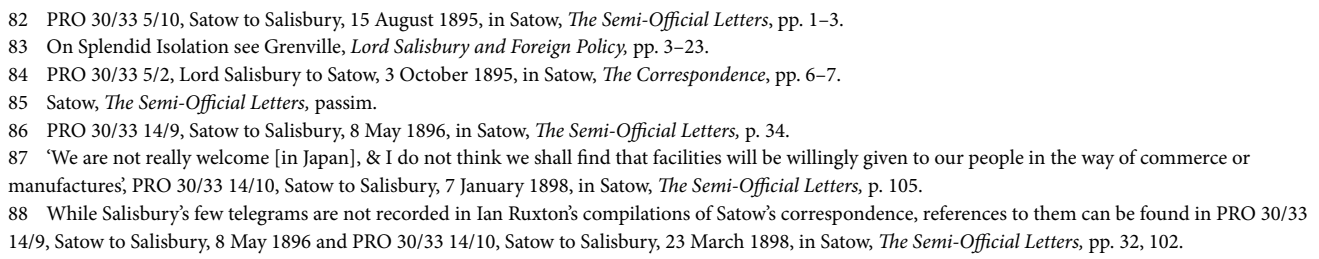


despatch to Satow assuring him that 'your letters are most interesting and you must not suppose they are not appreciated because you do not get answers from Lord Salisbury', and explaining that the Government was choosing to 'lie low as regards the Far Eastern Question'. ${ }^{89}$

Avoiding difficult decisions in Asia did not mean that the Foreign Office was as ignorant of Japan as it had been in the 1860s. A new generation of bureaucrats had come to power, to whom Japan was much more a known quantity than she had been thirty years before. After decades in which Japanese affairs were sidelined at the Foreign Office, a 'Far Eastern' department was finally formed in 1899, belatedly recognising Asia's importance in international diplomacy. ${ }^{90}$ Nonetheless, at a time when Britain faced a crumbling Turkish Empire, possible war with France over Africa and the beginnings of the Boer War, Japanese affairs were rather sidelined in Whitehall. ${ }^{11}$

Potentially, the telegraph could have revolutionised Anglo-Japanese diplomacy at the close of the nineteenth century, when Japan's growing rivalry with Russia gave the Foreign Office a golden opportunity to negotiate closer ties with Japan through the offices of Satow. In practice, while telegrams may have seemed to affect nearly every aspect of Satow's role, the core of his responsibilities was untouched.

\section{The Anglo-Japanese Alliance: 1900-1902}

The indifference from Whitehall during Satow's tenure quickly changed after his departure. In 1902 the Anglo-Japanese Alliance was signed, capping nearly half a century of diplomacy between Britain and Japan with an agreement of lasting significance. The Alliance signalled Britain's abandonment of strategic isolationism, and also symbolised that Japan had been accepted as a modern nation-state and regional power by Western decision-makers. The negotiations in 1900-1902 which preceded the Alliance also displayed the paradigm shift in diplomatic relations, to a world where the telegraph was paramount and the power of envoys and ambassadors diminished.

In 1900, Sir Ernest Satow exchanged postings with the British Minister to China, Sir Claude MacDonald (1852-1915), bringing Satow to Beijing and MacDonald to Tokyo. Within months of taking up his new post, MacDonald was recalled to London, ostensibly for leave but also to sound out his opinions on an alliance with Japan.

\footnotetext{
PRO 30/33 5/2, Eric Barrington to Satow, 29 September 1896, in Satow, The Correspondence, pp. 11-12.

90 Steeds and Nish, China, Japan and Nineteenth Century Britain, pp. 12-13.

91 For more detail on these events see Grenville, Lord Salisbury and Foreign Policy.
} 
MacDonald's return marked London as the focus for British discussion of a possible alliance, and showed the extent to which policy regarding Japan had been commandeered by the Cabinet. ${ }^{92}$ In the 1860 s British decisions on Japanese policy were for practical purposes being jointly taken by the Foreign Secretary and the Minister Plenipotentiary, but as Japan's importance on the world stage had increased so the decision-making process on Japanese matters had shifted away from the Minister on the spot and towards the Cabinet as a whole. MacDonald's opinion carried great weight and was personally sought by Salisbury, but his role in shaping policy seems to have been minimal. It was primarily Lord Lansdowne (Foreign Secretary 19001905) and Francis Bertie (head of the Asiatic Department at the Foreign Office) who constructed the Anglo-Japanese Alliance from the British side. After MacDonald returned to Tokyo, his role seems to have primarily been the delivery of drafts and counter-drafts from London to the Japanese government, although he continued to cable useful reports. ${ }^{93}$

To the last, Lord Salisbury remained uncertain of the wisdom of the Alliance. In the last major foreign policy memorandum of his career, the Prime Minister warned that it could see Britain dragged into an unwanted conflict over Korea. In his rebuttal to the argument that the alliance would allow for a quick reaction to a crisis, the old statesman finished with a familiar conviction on the flexibility offered by new technology:

The necessity for a decision so sudden that the telegraph will not be able to cope with the emergency is not a very probable contingency, and certainly does not furnish a justification for surrendering without reserve into the hands of another Power the right of deciding whether we shall or shall not stake the resources of the Empire on the issue of a mighty conflict. ${ }^{94}$

Salisbury saw that the very nature of state alliances had been undermined by the technology that had revolutionised nineteenth-century diplomacy. However, his misgivings were ignored. The Anglo-Japanese Alliance was signed on 30 January 1902, the first of several dramatic changes in the relationship between Britain and Japan in the new century. ${ }^{95}$ The nineteenth-century world of Alcock, Parkes and Satow had passed; and while the subsequent diplomats held the rank of Ambassador, their autonomy and consequence was never to reach the heights achieved by those three men. ${ }^{96}$ 


\section{Conclusion}

Historians such as Jones, Headrick and Nickles are right that the telegraph fundamentally altered the conduct of diplomacy. In the case of Japan and the United Kingdom, by 1900 the telegraph allowed the Foreign and Prime Ministers to play a much more handson role in negotiations than they could have a few decades before. While an AngloJapanese alliance would have been theoretically possible (if absurd) in the years before 1870 , it would have been exceedingly impractical to negotiate and implement without telegraphic communications.

Despite the degree to which the telegraph facilitated the alliance negotiations, this finding in itself does not completely bear out technologically determinist theories of the transformative power of technology. While the telegraph did end the unchecked gunboat diplomacy that had been a staple of British behaviour on the fringes of Empire in earlier decades, in most other fields the coming of the telegraph did not at first much modify a Minister's decision-making power. The Foreign Office was too busy, and lacked the necessary experience, to make regular judgements on the everyday problems that diplomats dealt with - especially since, for most of the nineteenth century, Japan was to them an exotic backwater. Its geographical position at the opposite side of the globe also made it particularly expensive to communicate with via cables. For these reasons, there was not enough incentive for the Foreign Office to micromanage the affairs of the man on the spot. The rise of Japan to foremost power in Asia, and the subsequent signing of the Anglo-Japanese Alliance in 1902, greatly increased the importance of Japan to the British, and marked the end of the independent envoy, ironically just before the position was officially upgraded to Ambassador.

There remains room for further research. Space limitations precluded an analysis here of the effect the telegraph had upon communication between Ministers stationed in neighbouring countries. Given the speed with which letters could be posted between Beijing and Japan, the telegraph would not have revolutionised the two consulates' relationship, but it might have allowed for closer cooperation on matters such as Korean policy. The time lag then, between potential centralised control, from 1870, and actual control, around 1901, shows that technological progress does not, in itself, drive history; it requires the will to utilise that technology by the people in power: a lesson that can be applied to a much wider canvas than Anglo-Japanese diplomacy. 


\section{References}

\section{PRIMARY SOURCES}

\section{Archive Sources}

British Foreign Office: Japan Correspondence, 1856-1905.

F.O. 46: 101, 102, 103, 125, 180, 189, 192, 200, 204.

\section{Printed Sources}

Bourne, K., and Watt, D. C., (general eds.), British Documents on Foreign Affairs: Reports and Papers from the Foreign Office Confidential Print. Part 1: From the Mid-Nineteenth Century to the First World War. Series E: Asia, 1860-1914. Vol. 1, Japan and North-East Asia, 1860-1878, Ian Nish (ed.) (Frederick, Maryland: University Publications of America, 1989).

British Parliamentary Papers, Japan 1: Reports, Returns and Correspondence Respecting Japan, 1856-64 (London: H.M.S.O., 1856-1864; reprint Shannon, Ireland: Irish University Press, 1971).

British Parliamentary Papers, Japan 2: Reports and Correspondence Respecting Japan, 1864-70 (London: Harrison and Sons, 1864-70; reprint Shannon, Ireland: Irish University Press, 1971).

British Parliamentary Papers, Japan 3: Reports, Correspondence, Returns and Dispatches Respecting Japan, 1871-99 (London: Harrison and Sons, 1871-1899; reprint Shannon, Ireland: Irish University Press, 1971).

Kajima, Morinosuke, The Diplomacy of Japan: Volume 2: Anglo-Japanese Alliance and Russo-Japanese War (Tokyo: Kajima Institute of International Peace, 1978).

Salisbury, Lord R. C., 'Speech to the Institution of Electrical Engineers', The Electrician, No. 599, Vol. 24 (8 November 1889), pp. 12-15.

Satow, E., in Ruxton, I. (ed.), The Correspondence of Sir Ernest Satow while he was British Minister in Japan, 1895-1900 (Kyūshū, Japan: Ian Ruxton, 2005).

Satow, E., in Ruxton, I. (ed.), The Diaries and Letters of Sir Ernest Mason Satow, 1843-1929, A Scholar-Diplomat in East Asia (Lewiston, New York: E. Mellen Press, 1998).

Satow, E., A Diplomat in Japan (London: Seeley \& Co., 1924; reprint, Tokyo, New York: Oxford University Press, 1968).

Satow, E., in Ruxton, I. (ed.), The Semi-Official Letters of British Envoy Sir Ernest Satow from Japan and China, 1895-1906 (Morrisville, North Carolina: Lulu Press, 2007).

\section{SECONDARY SOURCES}

Ahvenainen, J., The Far Eastern Telegraphs: The History of Telegraphic Communications Between the Far East, Europe, and America before the First World War (Helsinki: Suomalainen Tiedeakatemia, 1981).

Baark, E., Lightning Wires: The Telegraph and China's Technological Modernization, 1860-1890 (Westport, Connecticut: Greenwood Press, 1997).

Beasley, W. G., The Meiji Restoration (Stanford, California: Stanford University Press, 1972).

Checkland, O., Britain's Encounter with Meiji Japan, 1868-1912 (Basingstoke: Macmillan, 1989).

Cortazzi, H. (ed.), British Envoys in Japan, 1859-1972 (Folkestone, Kent: Global Oriental, 2004). 
New Voices Volume 3

Daniels, G., Sir Harry Parkes: British Representative in Japan, 1865-1883 (Richmond, Surrey: Japan Library, 1996).

Fox, G., Britain and Japan, 1858 - 1883 (Oxford: Clarendon Press, 1969).

Galbraith, J. S., 'The "Turbulent Frontier" as a Factor in British Expansion', Comparative Studies in Society and History, Vol. 2, No. 2, pp. 150-168 (Cambridge University Press, January 1960). Retrieved 18 August 2008, from http:// www.jstor.org/stable/177813.

Grenville, J. A. S., Lord Salisbury and Foreign Policy: The Close of the Nineteenth Century (London: University of London, Athlone Press, 1964).

Hane, M., Modern Japan: A Historical Survey (Boulder: Westview Press, 1986).

Headrick, D., The Invisible Weapon: Telecommunications and International Politics (New York: Oxford University Press, 1991).

Headrick, D., When Information Came of Age: Technologies of Knowledge in the Age of Reason and Revolution, 17001850 (Oxford: Oxford University Press, 2000).

Hurd, D., The Arrow War: An Anglo-Chinese Confusion (London: Collins, 1967).

Itoh, E., 'The Danish Monopoly on Telegraph in Japan', Keio Communication Review, No. 29 (2007), pp. 85-105.

Jansen, M., The Making of Modern Japan (Cambridge, Massachusetts: Harvard University Press, 2000).

Jones, R., The British Diplomatic Service: 1815-1914 (Gerrards Cross: Smythe, 1983).

Kajima, M., A Brief Diplomatic History of Modern Japan (Rutland, Vermont: Tuttle, 1965).

Nickles, D. P., Under the Wire: How the Telegraph Changed Diplomacy (Cambridge, Massachusetts: Harvard University Press, 2003).

Nish, I., The Anglo-Japanese Alliance: The Diplomacy of Two Island Empires, 1894-1907 (London: Athlone Press, 1966).

Nish, I. and Steeds, D., China, Japan and Nineteenth Century Britain (Dublin: Irish University Press, 1977).

Preston, A. and Major, J., Send a Gunboat! A Study of the Gunboat and its Role in British Policy, 1854-1904 (London: Longmans, 1967).

Satow, E., A Guide to Diplomatic Practice, 2 volumes, third edition (London: Longmans, 1922; reprinted Bristol: Ganesha Publishing; Tokyo: Edition Synapse, 1998).

Standage, T., The Victorian Internet: The Remarkable Story of the Telegraph and the Nineteenth Century's On-Line Pioneers (London: Weidenfeld \& Nicolson, 1998).

Williams, R., 'The Idea of “Technology” and Postmodern Pessimism', in Smith, M. R., and Marx, L., (general eds.), Does Technology Drive History: The Dilemma of Technological Determinism (Cambridge, Massachusetts: MIT Press, 1994), pp. 237-258.

Wong, J. Y., 'Harry Parkes and the "Arrow” War in China', in Modern Asian Studies, Vol. 9, No. 3 (1975), pp. $303-320$. Retrieved 10 May 2008, from http://www.jstor.org/stable/311739.

Yang, D., 'Colonial Korea in Japan's Imperial Communications Network', in Shin, G-W., and Robinson, M (eds.), Colonial Modernity in Korea (Cambridge, Massachusetts and London: Harvard University Asia Centre, 1999). 